\title{
STRATEGI PEMERINTAH DALAM PENANGGULANGAN COVID-19 PADA SEKRETARIAT SATUAN TUGAS PENANGANAN COVID-19 KOTA MAKASSAR
}

\author{
Andi Faradillah', Abdi², Nasrul Haq $^{3}$ \\ 1,2, 3 Ilmu Administrasi Negara, Fisip Unismuh Makassar \\ andifardillah79@gmail.com
}

\begin{abstract}
This study purposed to find out the government's strategy in dealing with Covid-19 at the Makassar City Covid19 Task Force Secretariat. This study used descriptive qualitative. The data sources in this study were primary data sources and secondary data sources with the number of informants as many as 8 people. Data collection techniques using the method of observation, interviews and documentation. The results of this study were 1) the organizational strategy in dealing with Covid-19 in the Makassar city covid-19 handling task force that the vision and mission of the covid-19 handling unit were not stated. 2) The program strategy in dealing with COVID-19 in the Makassar City Covid-19 handling task force had been carried out to the maximum, seen from the linkage between the program and the tasks assigned. 3) The strategy to support resources in dealing with Covid-19 required a budget called Unexpected Costs (BTT) obtained from the APBD. 4) In the institutional strategy, several strategies were taken by the government in accelerating the handling of Covid-19, namely the first strategy, which was an increase in $3 \mathrm{M}$, namely wearing masks, washing hands, maintaining distance.
\end{abstract}

Keywords: Strategy, Government, Covid-19 Response

\begin{abstract}
Abstrak
Penelitian ini bertujuan untuk mengetahui strategi pemerintah dalam penanggulangan Covid-19 pada Sekretariat Satuan Tugas Penangnan Covid-19 Kota Makassar. Jenis penelitian yang digunakan deskriptif kualitatif dan menggunakan tipe penelitian kualitatif. Adapun sumber data dalam penelitian ini adalah sumber data primer dan sumber data skunder dengan jumlah informan sebanyak 8 orang. Teknik pengumpulan data dengan menggunakan metode observasi, wawancara dan dokumentasi. Hasil dari penelitian ini adalah 1) Strategi organisasi dalam penanggulangan Covid-19 pada satuan tugas Penanganan covi-19 kota Makassar bahwa visi dan misi pada satuan penanganan covid-19 tidak dijabarkan atau tidak tertuang. 2) Strategi program dalam penanggulangan covid-19 pada satuan tugas penanganan covid-19 kota Makassar telah dilaksanakan dengan maksimal, dilihat dari keterkaitan antara program dan tugas yang diberikan. 3) Strategi pendukung sumber daya dalam penanggulangan Covid-19 memerlukan anggaran yang dinamakan Biaya Tak Terduga (BTT) yang didapatkan dari APBD. 4) Dalam Strategi kelembagaan beberapa strategi yang diambil oleh pemerintah dalam percepatan penanganan Covid-19 yaitu Strategi pertama, adalah peningkatan 3 M yaitu memakai masker, mencuci tangan, menjaga jarakk.
\end{abstract}

Kata kunci : Strategi, Pemerintah, Penanggulangan Covid-19.

\section{PENDAHULUAN}

Novel Corona Virus atau yang biasa dikenal dengan Corona Virus Disease (Covid19) merupakan sebuah penyakit (virus) yang pertama kali muncul di Negara Cina pada awal Desember 2019. Penyakit (virus) ini di umumkan secara resmi pada tanggal 31 Desember 2019 yang mengakibatkan 41 orang terinfeksi dan 1 orang dinyatakan meninggal dunia akibat penyakit (virus) ini. World Health Organizaiton atau biasa di sebut WHO mengatakan bahwa virus ini berasal dari hewan yang di perjual belikan secara bebas di Wuhan, Cina.

Salah satu strategi yang dilakukan oleh pemerintah kota Makassar untuk mencegah penyebaran Covid-19 yaitu Pembatasan Sosial Berskala Besar (PSBB) diberlakukan di seluruh wilayah Makassar sesuai dengan 
keputusan Mentri Kesehatan Republik Indonesia Nomor HK .01.07/Menkes/257/2020 tentang Penetapan Pembatasan Sosial Berskala Besar diwilayah kota Makassar Sulawesi Selatan dalam Rangka Percepatan Penanganan Corona Virus Disease 2019 (Covid-19). Pelanggaran PSBB dapat dijatuhi sanksi pidana sebagaimana yang tertera dalam pasal 121 KUHP, Pasal 214 KUHP Pasal 216 atau Pasal 218 KUHP, dan pasal yang mengatur tentang Pengendalian Wabah Penyakit.

Pemerintah kota Makassar telah membentuk Satuan Tugas (Satgas) Penanganan Covid-19 di Kota Makassar menyusul berakirnya massa tugas Gugus Tugas Percepatan Penanganan Covid-19 setempat yang telah bekerja sejak bulan April 2020. Satgas Covid-19 ini resmi dibentuk oleh $\mathrm{Pj}$ Walikota Makassar untuk penanganan Covid-19 Kota Makassar pada tanggal 26 Oktober 2020..

Adapun penelitian terdahulu yang dilakukan sebagai salah satu faktor pendukung yang dapat membantu penyelesaian penelitian ini terkhususnya dengan penelitian terdahulu yang mempunyai tema dan variabel yang sama atau yang berkaitan dengan judul peneliti diantaranya yaitu sebagai berikut: (1) Penelitian ini dilakukan oleh Gerry R. J. Wonok, (2020) Strategi Pemerintah Desa Dalam Pencegahan Penyebaran Virus Corona (Covid-19) (Studi di Desa Mokobang Kecamatan Modoinding Kabupaten Minahasa Selatan). Pandemi COVID-19 telah membuat pemerintah baik di tingkat pusat hingga ketingkat terendah seperti pemerintah desa, terpaksa harus memikirkan berbagai strategi yang harus dilakukan dalam mencegah penyebarannya. Walaupun protocol standar telah ditentukan yaitu : memakai masker, mencuci tangan, dan menjaga jarak yang dikenal dengan $3 \mathrm{M}$, namun dalam implementasinya terbukti masih banyak masyarakat yang melanggar bahkan tidak perduli. Untuk itu diperlukan strategi tambahan agar ketaatan masyarakat bisa tumbuh terhadap anjuran pemerintah tersebut. Di desa Mokobang pemerintah desa dalam hal penanganan pandemic COVID-19, melakukan beberapa strategi, diantaranya memaksimalkan berbagai sumber daya yang dimiliki baik itu yang diberikan oleh pemerintah pusat, pemerintah daerah, bahkan partisipasi masyarakat. Strategi yang juga pemerintah desa seperti membuat pos penjagaan keluar masuk orang, mewajibkan masyarakatyang masuk ke desa mencuci tangan, dan mewajibkan surat kewaspadaan bagi orang yang berasal dari luar kecamatan Modoinding. Bahkan berbagai kegiatan Ibadah, social, budaya dibatasi dengan ketentuan standar protocol kesehatan. Selain itu pemberdayaan aparat desa juga dilakukan semaksimal mungkin. Namun problematika penangganan pandemic COVID-19 di desa Mokobang, masih ada akibat tingkat pendidikan masyarakat yang terbilang rendah yang mengakibatkan sosialisasi pemahaman pandemic tersebut sulit di mengerti oleh masyarakat. Akibatnya strategi pemerintah desa tersebut menjadi kurang efektif dimana terlihat pos penjagaan sering tidak ada yang menjaga sehingga masuk keluar orang otomatis tidak diawasi, masih adanya kegiatan perkumpulan yang melibatkan lebih dari 20 orang, banyak masyarakat yang belum sadar akan protocol kesehatan, dalam hal ini yang berkaitan dengan penelitian yang akan saya teliti juga tentang penyakit (wabah) menular, antara lain penelitian (2) Rakhman, (2017) Peran Pemerintah Daerah dalam Pencegahan dan Penanggulangan HIV-AIDS di Kabupaten Merauke. Adapun upaya yang dilakukan oleh pemerintah Kabupaten merauke diantaranya dibidang pencegahan yaitu Meningkatkan Komunikasi, informasi dan edukasi, Meningkatkan penggunaan kondom, Meningkatkan upaya penurunan prevalensi Penyakit Infeksi menular, Meningkatkan upaya pencegahan penularan hiv dari ibu ke bayi, Meningkatkan kewaspadaan universal, pembinaan dan pelatihan keterampilan untuk pekerja seks, Sosialisasi Peraturan No. 3 Tahun 2013 tentang pencegahan dan penanggulangan IMS, HIV dan AIDS, Sosialisasi kondom kreatif, Sosialisasi HIVAIDS di sekolah, Pelatihan educater (pendidikan sebaya), kampanye anti diskriminasi ODHA. Adapun upaya pemerintah dibidang penanggulangan diantaranya adalah Program VCT yang bertujuan untuk memberikan layanan konseling dan Tes HIV kepada masyarakat, dan layanan pengobatan dan dukungan ODHA yang bertujuan untuk meningkatkan mutu hidup ODHA. (3) Susianti (2018) "Strategi Pemerintah Dalam Program Pemberantasan Demam Berdarah Dengue (Dbd) Di 
Kabupaten Merangin Provinsi Jambi" Pelaksanaan pemberantasan DBD di Kabupaten Merangin berdasarkan aspek-aspek implementasi pemberantasan DBD masih belum optimal, belum terintegrasinya kegiatan pemberantasan terutama gerakan Pemberantasan Sarang Nyamuk (PSN) secara rutin dan mandiri dengan keterlibatan masyarakat dan sektor terkait. Dukungan Kepala Daerah Kabupaten Merangin dalam keterlibatan semua sektor dan masyarakat di dalam mengampanyekan gerakan satu rumah satu jumantik sebagai wujud PSN merupakan strategi utama yang harus segera dilakukan. (4) Fadhul (2000), "Analisis Peningkatan Startegi Dalam Penanggulangan Penyakit TBC Di Puskesmas Rejosaari Kabupaten Kudus". Sesuai data Dinas Kesehatan Kota (DKK) di Kabupaten Kudus 2011, dalam kesuksesan program pemberantasan kasus TBC Paru menjadi salah satunya yang diliat dari angka kesembuhan penderita TBC Paru. Untuk mencegah peningkatan penjangkitan penyakit TBC baru, pemerintah Kabupaten Kudus menggunakan strategi DOTS (Directly Observed Treatment Shortcourse) untuk memberantas TBC Paru. Puskesmas Rejosari telah melakukah Strategi DOTS (Directly Observed Treatment Shortcourse) dan diawasi oleh petugas kesehatan. Puskesmas Rejosari memiliki laboratorium yang akan memeriksa spuntum dan akan di kerjakan oleh petugas analisi kesehatan Strategi yang telah dilakukan mencapai tingkat kesembuhan yang memuaskan.

Hal serupa disampaikan Djatmiko (2008:4) yang mengatakan bahwa strategi merupakan suatu cara dimana organisasi akan mencapai tujuan-tujuannya, sesuai dengan peluang-peluang dan ancaman-ancaman lingkungan eksternal yang dihadapi serta sumber daya dan kemampuan internal organisasi.

Menurut Effendy (2004:300) strategi pada hakikatnya adalah perencanaan (planning) dan manajemen (management) untuk mencapai suatu tujuan yang telah di tentukan.

Menururt Kotten dalam Salusu (2008:104) tipe-tipe strategi meliputi: (1) Strategi Organisasi (Corporate Strategy) berkaitan dengan apa yang menjadi perumusan suatu misi, tujuan, nilai-nilai, dan inisiatifinisiatif strategi yang baru. Pembatasanpembatasn yang diperlukan, yaitu apa yang ingin dilakukan dan untuk siapa hal tersebut, (2) Strategi Program (Program Strategi) Strategi ini lebih memberi perhatian pada implikasi-implikasi strategis dari suatu program tertentu. Apa kira-kira dampaknya apabila suatu program dilancarkan atau diperkenalkan, apa dampaknya bagi sasaran organisasi tersebut, (3) Resource Support Strategy (strategi pendukung sumber daya). Strategi sumber daya ini memusatkan perhatiannya pada memaksimalkan pemanfaatan sumber -sumber daya penting yang tersedia guna meningkatkan kualitas kinerja sebuah organisasi. Sumber daya itu dapat berupa tenaga, keuangan, teknologi, dan sebagainya. (4) Strategi Kelembagaan (Institutional Strategy) Fokus dari strategi kelembagaan yaitu mengembangkan kemampuan sebuah organisasi untuk melaksanakan atau menjalankan inisiatifinisiatif strategi. Pada umumnya bentukbentuk strategi yang telah dikemukakan di atas, secara garis besar menjelaskan hal yang sama yakni tingkatan atau tipe - tipe strategi apa saja yang dapat digunakan untuk mengembangkan sebuah organisasi.

Menurut Siagian (2007:15), manajemen strategi merupakan serangkaian tindakan dan keputusan yang mendasar dibuat oleh seluruh jajaran suatu organisasi yang dalam hal ini untuk pencapaian tujuan organisasi tersebut.

Sedangkan menurut Vuljoen dalam Henne (2010:76) mengemukakan bahwa manajemen strategi yaitu suatu proses dari pemilih, pengidentifikasian dan pengimplementasian aktivitas-aktivitas yang dapat memperbaiki kinerja dalam jangka panjang dari suatu organisasi, melalui penentuan arah dan disertai dengan melanjutkan komitmen ataupun penyesuaian antara keterampilan internal dengan saranasarana dari organisasi berikut pula dengan keadan evolutif yang dimana organisasi itu beoperasi

Menurut Houthoofd dalam Heene (2010:76) manajemen strategis didefinisikan sebagai suatu proses di mana organisasi menata diri demi tercapainya tujuan-tujuan keorganisasian melalui cara: (1) Analisis strategi yang proporsional (2) Perumusan strategi yang dijadikan keunggulannya, (3) Pengimplementasian strategi yang akurat; dan (4) Pengevaluasian kontinum terhadap kinerjanya. 
Menurut Imam Mulyana strategi adalah Ilmu seni menggunakan kemampuan bersama sumber daya dan lingkungan dan dan tujuan, empat unsur tersebut sedemikian rupa diastuka secara rasional dan indah sehingga muncul beberapa alternative pilihan yang kemudian dievaluasi dan diambil yang terbaik.

Hal ini senada dengan yang disampaikan oleh David (2002:15) bahwa tujuan dari startegi adalah untuk membantu oganisasi mencapai tujuan dengan menggunakan pendekatan yang lebih sistematis, logis, rasional pada tersedianya pilihan-pilihan strategis.

Sedangkan menurut Peace dan Robinson (1997:30-31) yang dimana menyatakan bahwa strategi berfungsi untuk: (1) Kegiatan perumusan (formulasi) strategi ini memperkuat organisasi agar mencegah masalah. Manager yang dimana mendorong bawahannya agar memfokuskan pada suatu perencanaan dalam melaksanakan tanggung jawab dan menyadari bahwa perlunya perencanaan strategic, (2) Keputusan strategi yang dimana di dasarkan pada suatu kelompok yang dihasilkan dari alternative terbaik yang ada. tidak lebih senang dengan keputusan mereka sendiri ketimbang jika keputusan diambil secara otoriter, kesadaran mereka yang lebih besar akan parameter-parameter yang membatasi pilihan membuat mereka lebih mau menerima keputusan ini.

Menurut Better $(2002,99)$ terdapat enam prinsip keberlanjutan dalam perspektif penanggulangan antara lain : (1) mempertahankan dan meningkatkan kualitas hidup, (2) meningkatkan vitalitas ekonomi (3) memastikan kesetaraan sosial antar generasi, (4) mempertahankan dan meningkatkan kualitas lingkungan, (5) memasukkan ketahanan terhadap bencana dan mitigasi kedalam aksi dan keputusan, (6) menggunakan proses pencapaian consensus yang partisipatif ketika membuat keputusan.

\section{METODE}

Waktu Dan Tempat Penelitian ini dilaksanakan pada tanggal Penelitian ini dilaksanakan pada tanggal 11 Januari sampai dengan 11 Maret di Sekretariat Satuan Tugas (Satgas) Penanganan Covid-19 Kota Makassar yang berlokasi di Baruga Angin Mamiri Jl. H.I.A. Saleh Dg. Tompo No. 33,
Losari, Kecamatan Ujung Pandang Kota Makassar, Sulawesi Selatan. Adapun alasan peneliti pemilihan lokasi didasarkan atas dasar bahwa Satgas dibentuk berdasarkan rujukan dari Pemprov Sulsel dalam percepatan penanganan Covid-19 di Kota Makassar (1) Jenis Dan Tipe Penelitian, Adapun jenis penelitian ini adalah jenis penelitian kualitatif bersifat deskriptif penelitian ini bertujuan untuk mendeskripsikan, mencatat, dan menginterpretasikan kondisi yang terjadi di lokasi penelitian dengan fakta yang ada di lapangan. (2) Penelitian ini menggunakan tipe penelitian kualitatif dimana peneliti menggunakan landasan teori untuk menjadi bahan referensi sebagai panduan agar fokus penelitian sesuai dengan fakta di lapangan.

Informan dalam penelitian ini berjumlah 8 orang. Informan penelitian yang dimaksud adalah aparat/birokrat yang berperan dan bertanggungjawab dalam strategi penanggulangan Covid-19 di Kota Makassar serta orang-orang yang terlibat langsung dalam penanggulangan Covid-19 dan di anggap memiliki informasi penting dan pengetahuan tentang apa yang berkaitan dengan tujuan dan harapan peneliti.

Teknik Pengumpulan (1) Observasi yaitu metode pengumpulan data yang digunakan dengan cara melakukan pengamatan secara langsung di lapangan (2) Wawancara yaitu wawancara bebas terpimpin, artinya peneliti mengadakan pertemuan langsung dengan yang bersangkutan dan wawancara bebas artinya peneliti bebas mengajukan pertanyaan kepada informan atau masyarakat sesuai dengan jenis data dan informasi yang dibutuhkan dalam penelitian ini. (3) Dokumentasi yaitu pemanfaatan informal melalui dokumendokumen tertentu yang berkaitan dengan Strategi Pemerintah dalam Penanggulangan Covid 19 Di Kota Makassar

Teknik Analisis Data, merupakan alat yang digunakan oleh peneliti untuk mengelolah data menjadi hasil penelitian dimana data yang diperoleh melalui observasi dan wawancara di lapangan. Ada 3 komponen yang di jelaskan oleh Sugiyono (2017:247252) yaitu: (1) Reduksi data, yaitu merangkum dan menfokuskan pada hal-hal penting yang berkaitan dengan Penyajian Data Strategi Pemerintah dalam Penanggulangan Covid-19 di Kota Makassar. (2) Penyajian data adalah kegiatan yang dilakukan oleh peneliti 
untuk mengumpulkan dan menyususun informasi sehingga dapat memberikan kesimpulan mengenai informasi yang didapatkan dari objek yang diteliti dalam hal Strategi Pemerintah dalam Penanggulangan Covid 19 di Kota Makassar.

Menurut Sugiyono (2017:274), ada tiga (3) macam triangulasi yaitu: (1) Triangulasi sumber yaitu membandingkan dengan cara mengecek derajat kepercayaan suatu informasi yang diperoleh melalui sumber yang berbeda. (2) Triangulasi teknik untuk menguji kredibilitas data yang dilakukan dengan cara mengecek data kepada sumber yang sama dengan teknik yang berbeda. (3) Triangulasi waktu juga sering mempengaruhi kredibilitas data.

\section{HASIL DAN PEMBAHASAN}

Dalam penanggulangan Covid-19 Kota Makassar memerlukan strategi yang baik agar dapat meminimalisir penyebaran Covid-19, Dalam rangka mengfokuskan arah dalam penelitian ini, peneliti mengunakan teori strategi menurut menurut Kotten dalam Salusu (2008:104), yang menetapkan empat unsur penting dalam pengertian strategi yaitu Strategi Organisasi, Strategi Pendukung Sumber Daya, Strategi Program, Strategi Kelembagaan yang dimana Untuk mengembangkan kemampuan organisasi dalam melaksanakan inisiatif-inisiatif strategi. Untuk strategi pendukung sumber daya dapat berupa sumberdaya seperti tenaga, teknologi dan sebagainya. Selanjutnya strategi program dapat berupa berbagai kegiatan peningkatan strategi pada unit-unit kesehatan yang selaras dengan tujuan yang hendak di capai, sehingga dapat menjadi nilai untuk mencapai keberhasilan.

\section{Strategi Organisasi (Corporate Strategy)}

Untuk melihat strategi organisasi maka peneliti melihat dari tujuan tersebut. Menurut Marrus (2002:31) strategi didefenisikan sebagai suatu proses penentuan rencana para pemimpin puncak yang berfokus pada tujuan jangka panjang organisasi, disertai penyusunan dan upaya agar tujuan tersebut dapat tercapai. Jadi pada dasarnya strategi adalah alat untuk mecapai suatu tujuan. Dalam pembentukan Satgas Covid-19 Kota Makassar yang tertera dalam Peraturan Walikota Makassar Tentang Pembentukan Satuan Tugas Penanganan
Corona Virus Disease 19 Kota Makassar untuk membatu pemerintah dan masyarakat dalam penanganan Covid-19.

Dalam Strategi organisasi pada Satgas Covid-19 khususnya Kota Makassar bertujuan sebagai berikut : (a) Meningkatkan ketahanan Nasional di bidang kesehatan, (b) Mempercepat penanganan Covid-19 melalui sinergi antar kementrian/lembaga dan pemerintah daerah, (c) Meningkatkan antisipasi perkembangan eskalasi penyebaran Covid-19, (d) Meningkatkan sinergi pengambilan kebijakan operasional, (e) Meningkatkan kesiapan dan kemampuan dama mencegah, mendeteksi dan merespon terhadap Covid-19

\section{Strategi Program (Program Strategy)}

Menurut Anthony dan Govindarajan (2005) strategi yaitu suatu proses dalam manajemen yang sistematis yang didefenisikan sebagai proses dalam pengambilan keputusan atas program-program yang akan dilaksanakan oleh organisasi dan perkiraan sumber daya yang ada. Suatu proses perencanan pasti akan berhadapan dengan berbagai tingkat kegagalan. Beberapa bagian organisasi memerlukan perencanaan selama bertahuntahun kedepan, namun untuk devisi lain memerlukan waktu singkat. Hal ini juga dapat didefenisikan sebagai proses penentuan tujuan organisasi dan sumber daya yang akan digunakan untuk menangani tujuan organisasi, mengatur akuisi, pemanfaatan dan disposisi sumber daya.

Program-program yang di jalankan oleh Satgas Covid-19 Kota Makassar telah berjalan dengan maksimal. Program yang dijalankan itu agar dapat meminimalisir penyebaran covid19. Namun dalam menjalankan tugas tidak terlepas dari beberapa faktor yaitu Dalam melakukan penanganan Covid-19 khususnya kota Makassar masih menemukan kendala yang dimana masih kurangnya kesadaran masyarakat dalam mematuhi protokol kesehatan dan faktor inilah yang memeberikan dampak yang luar biasa. Akan tetapi dari hasil penelitian yang dilakukan peneliti bahwasannya Tim Satgas Covid-19 Kota Makassar tak pernah lelah untuk selalu memberikan edukasi kepada masyarakat untuk tetap Mematuhi protokol kesehatan agar dapat meminimalisir penyebaran Covid-19. 


\section{Strategi Pendukung Sumber Daya (Resource Support Strategy)}

Dalam Strategi Sumber Daya yang ada di Satgas Covid-19 Kota Makassar dilahat dari penjelasan diatas mengenai penyebaran Covid19 dan dampak yang ditimbulkan dari segi kesehatan dan dari segi ekonomi maka dari itu dalam menanggulangi covid-19 di Kota Makassar Memerlukan anggaran yang dinamakan Biaya Tak Terduga (BTT) yang didapatkan dari APBD melalui rekofusing persial pengurangan anggaran yang untuk dijadikan anggaran Biaya Tak Terduga (BTT) sesuai dalam Peraturan Presiden Nomor 82 Tahun 2020 Tentang Komite Penanganan Corona Virus Disease 2019 (Covid-19) Dan Pemulihan Ekonomi Nasional.

Belanja Tak Terduga (BTT) adalah pengeluaran anggaran untuk kegiatan yang sifatnya tidak biasa dan tidak diharapkan berulang seperti penanggulangan bencana alam, bencana sosial dan biaya tidak terduga lainnya yang sangan diperlukan dalam rangka penyelenggaraan kewenangan pemerintah pusat atau daerah.

\section{Strategi Kelembagaan (Institutional Strategy)}

Menurut Koentjaraningrat, (1997, h 15) kata kelembagaan merujuk kepada suatu yang bersifat mantap (established) yang hidup (constituted) didalam masyarakat. Koentjarangrat juga menjelaskan (1997, h 16) bahwa suatu kelembagaan adalah suatu pemantapan perilaku (ways) yang hidup pada suatu kelompok orang, sehingga kelembagaan merupakan suatu yang stabil, mantap, dan berpola, berfungsi untuk tujuan-tujuan tertentu dalam masyarakat: ditentukan dalam system sosial tradisional dan modern, atau bisa berbentuk tradisional dan poderen dan berfungsi untuk mengefisienkan kehidupan sosial.

Sedangkan kelembagaan menurut Hendropuspito (1989) merupakan suatu bentuk organisasi yang secara tetap tersusun dari polapola kelakukan, peran-peran dan relasi sebagai cara mengikat guna tercapainya kebutuhankebutuhan sosial dasar. Senentara itu Taneko (1993) mendefenisikan kelembagaan sebagai adanya norma-norma dan kebutuhankebutuhan masyarakat dalam situasi tersebut. Dengan demikian lahirnya kelembagaan dimasyarakat sebagai bentuk aturan (rule) yang ada dan mengikat guna untuk memperoleh serta memenuhi kebutuhan masyarakat dalam kegidupan sosial.

Berdasarkan defenisi menurut empat pakar diatas, dapat disimpulkan bahwa kelembagaan hadir dimayarakat karna kondisi masyarakat dipenuhi oleh berbagai aturan dan perilaku dengan malihat aturan-aturan tersebut. Strategi ini berbicara tentang bagaimana mengembangkan kemampuan sebuah organisasi untuk melaksanakan atau menjalankan inisiatif-inisiatif strategi.

Ada beberapa strategi yang diambil oleh pemerintah dalam percepatan penanganan Covid-19 yaitu Strategi pertama, adalah peningkatan $3 \mathrm{M}$ yaitu memakai masker, mencuci tangan, menjaga jarakk. Strategi yang ke dua adalah memaksimalkan $3 \mathrm{~T}$ yaitu Testing, tracing dan treatment. Upaya testing dilakukan dengan memastikan jumlah laboratorium cukup untuk melakukan pengetesan. Kemudian tracing dilakukan untuk membendung penularan yang terjadi di masyarakat dan treatment dilakukan agar setiap pasien yang positif bisa sembuh kembali. Strategi yang ke tiga adalah koordinasi pusat antar daerah.

\section{KESIMPULAN}

Berdasarkan hasil dari penelitian Strategi Pemerintah Dalam Penanggulangan Covid-19 Pada Satuan Tugas Penanganan Covid-19 Kota Makassar maka dapat disimpulkan bahwa : (1) Strategi organisasi dalam penanggulangan Covid-19 pada satuan tugas Penanganan covi-19 kota Makassar bahwa visi dan misi pada satuan penanganan covid-19 tidak dijabarkan atau tidak tertuang akan tetapi dapat dilihat dari Tugas-tugasnya, (2)Strategi program dalam penanggulangan covid-19 pada satuan tugas penanganan covid-19 kota Makassar telah dilaksanakan dengan maksimal, dilihat dari keterkaitan antara program dan tugas yang diberikan. Akan tetapi masih ada hambatan dilihat dari jumlah yang positif tiap harinya selalu ada bahkan jumlah yang sembuh lebih sedikit dari yang positif tiap harinya, (3) Strategi pendukung sumber daya dalam penanggulangan Covid-19 pada satuan tugas penanganan Covid-19 Kota Makassar dalam menanggulangi covid-19 di Kota Makassar Memerlukan anggaran yang 
dinamakan Biaya Tak Terduga (BTT) yang didapatkan dari APBD melalui rekofusing persial pengurangan anggaran yang untuk dijadikan anggaran Biaya Tak Terduga (BTT) sesuai dalam Peraturan Presiden Nomor 82 Tahun 2020 Tentang Komite Penanganan Corona Virus Disease 2019 (Covid-19) Dan Pemulihan Ekonomi Nasional, (4) Dalam Strategi kelembagaan ada beberapa strategi yang diambil oleh pemerintah dalam percepatan penanganan Covid-19 yaitu Strategi pertama, adalah peningkatan $3 \mathrm{M}$ yaitu memakai masker, mencuci tangan, menjaga jarakk. Strategi yang ke dua adalah memaksimalkan $3 \mathrm{~T}$ yaitu Testing, tracing dan treatment.

\section{REFERENSI}

Anthony, Dkk. (2005). Manajemen Control System. Jakarta : Selemba Empat

Amir. (2011). Manajemen Strategik. Yogyakarta: Rajawali Pers

Amirullah. (2015). Manajemen Srategi : Teori, Konsep, Kinerja. Jakarta: Mitra Wacana Media

Bryson, J.M. (2005). Perencanaan Strategis bagi Organisasi Sosial. Edisi Terjemahan, Yogyakarta : Pustaka Pelajar.

Buana, (2020). Analisis Perilku Masyarakat Indonesia dalam Menghadapi Pandemi Virus Corona (Covid-19) dan Kiat Menjaga Kesejahteraan Jiwa.

David, F.R. (2002). Manajemen Strategis : Konsep. Jakarta : Salemba Empat.

Dirgantoro. (2001). Manajemen Stratejik : Konsep, Kasus Dan Implementasi. Jakarta : Grosindo

Djatmiko. (2004). Perilaku Organisasi. Bandung : Alfabeta.

Effendi. (2004). Ilmu Komunikasi Teori dan Praktek. Bandung: Rasda Karya

Fadhul. (2000). Analisis Peningkatan Startegi Dalam Penanggulangan Penyakit TBC
Di Puskesmas Rejosaari Kabupaten Kudus. (Skripsi, Aceh Barat : Universitas Teuku Umar).

Gerry R. J. Wonok. (2020). Strategi Pemerintah Desa Dalam Pencegahan Penyebaran Virus Corona (Covid1-19) (Studi di Desa Mokobang Kecamatan Modoinding Kabupaten Minahasa Selatan). Jurnal Ilmu Pemerintahan Fisip Unsrat

Marrus. (2002). Desain Penelitian Manajemen Strategik. Jakarta : Rajawali Press

Moleong, L.J. (2007). Metodologi Penelitian Kualitatif. Bandung : Remaja Rosdakarya.

Nurjannah, dkk. (2011). Manajemen Bencana. Bandung: Alfabeta.

Pearce dan Robinson. (1997). Manajemen Strategis. Jakarta : Bina Rupa Aksara.

Rakhman. (2017). Peran Pemerintah Daerah dalam Pencegahan dan Penanggulangan HIV-AIDS di Kabupaten Merauke. Jurnal Ilmu Pemerintahan, volume 10 (1), 20-29.

Salusu. (2008). Pengambilan Keputusan Strategi. Jakarta : PT. Gramedia Pustaka Utama

Siagian. (2007). Fungsi-Fungsi Manajerial. Jakarta : Bumi Aksara

Sugiyono. (2017). Metode Penelitian Kuantitatif, Kualitatif, dan $R \& D$. Bandung: Alfabeta.

Susianti. (2018). Strategi Pemerintah Dalam Program Pemberantasa Demam Berdarah Dengue (Dbd) Di Kabupaten Merangin Provinsi Jambi. Jurnal buletin penelitian system kesehatan, volume 22, Halaman 1-8.

Sutarto. (2012). Dasar-Dasar Organisasi. Yogyakarta: Gadjah Mada University Press

Suwandi. (2008). Memahami Penelitian Kualitatif. Jakarta : Rineka Cipta.

Syafiee. (2011). Manajemen Pemerintahan. Bandung : PT Rineka Cipta. 
Taufiq. (2011). Manajemen Strategik : Konsep dan Aplikas). Jakarta: PT. Rajagrafindo Persada.

Wahyudi. (1996). Manajemen Strategik : Pengantar Proses Berpikir Strategik. Jakarta : Bumi Aksara. 